\title{
Old and new strategies for the prevention of nosocomial infections
}

\author{
Ilaria Stolfi ${ }^{*}$, Carla Fassi ${ }^{1}$, Roberto Pedicino ${ }^{2}$, Luigi Giannini ${ }^{3}$ \\ From XXI Congress of the Italian Society of Neonatology \\ Palermo, Italy. 24-26 September 2015
}

Nosocomial infections are a significant issue of public health. In Italy, the incidence of nosocomial infections range between 5 and $8 \%$ [1]; in Neonatal Intensive Care Unit (NICU) range between 7 and 24.5\% [2].

Nosocomial infection in a newborn is defined as an infection arised after 48-72 hours of hospitalization. The extremely low birth weight (ELBW) neonates have an increased risk of developing infections (40\%) [2], due to the immaturity of the immune system, the prolonged length of hospitalization and the frequent need for invasive procedures (central venous catheters - CVC, mechanical ventilation, parenteral nutrition, prolonged antibiotic therapies). In NICU, sepsis accounted for 45$55 \%$ of cases of nosocomial infections, followed by the lower respiratory tract infections (16-33\%), skin and soft tissue infections (26.3\%), urinary tract infections (8-19\%) and meningitis $(9.6 \%)$ [2]. The gram-positive bacteria are responsible for $65 \%$ of infections (Coagulase-negative Staphylococci - CoNS, Staphylococcus aureus and Enterococcus spp respectively in 50, 35 and 6\% of cases), followed by Gram-negative bacteria (Klebsiella, Pseudomonas, E. Coli ) and fungi in $25 \%$ of cases each. Candida albicans is involved in $50 \%$ of cases of fungal infections. Viruses are accountable for epidemics in the NICU, but the incidence of viral infections is likely to be underestimated.

The prevention of nosocomial infections is an essential element for the management of the newborns $[3,4]$ and is based on strategies to reduce the risk factors related to the newborn (immune system, carefull skin care, etc.) and to improve the invasive care procedures (implementation and dissemination of guide lines for

\footnotetext{
* Correspondence: ilaria.stolfi@gmail.com

'Department of Obstetrics and Gynecology, Newborn Emergency Transport Service (STEN), Umberto I Policlinico of Rome, University hospital, Sapienza University of Rome, 00161, Italy

Full list of author information is available at the end of the article
}

accurate and proper hand hygiene [4,5], for prevention of CVC related infections $[4,6]$ and ventilator-associated pneumonia [7], promotion of enteral feeding with breast milk [8]). Not least, the need for accurate diagnostic strategies for early detection of neonatal infections and a rational use of antimicrobial therapies and antibiotic prophylaxis $[9,10]$. The new strategies of prophylaxis of infections involving the use of bioactive substances with anti-infective properties, such as lactoferrin [11]; the use of probiotics, which have recognized immunomodulatory and anti-infectious activities [12]; the prophylaxis with antifungal drugs [13]. Lastly, NICU should also meet specific criteria of organization, providing to maintain an adequate ratio nurses/beds, avoid overcrowding and understaffing, make easily available devices for hand washing, organize meetings for training/provide to caregivers regular feedback of performance data, plan continuous monitoring and a surveillance system of the rate of nosocomial infections and avoid preventive measures of unproven effectiveness.

\section{Authors' details}

'Department of Obstetrics and Gynecology, Newborn Emergency Transport Service (STEN), Umberto I Policlinico of Rome, University hospital, Sapienza University of Rome, 00161, Italy. '2Department of Obstetrics and Gynecology, Neonatal Intensive Care Unit, Umberto I Policlinico of Rome, University hospital, Sapienza University of Rome, 00161, Italy. ${ }^{3}$ Department of Pediatrics, Umberto I Policlinico of Rome, University hospital, Sapienza University of Rome, 00161, Italy.

Published: 24 September 2015

\section{References}

1. Istituto Superiore di Sanità: Infezioni correlate all'assistenza. Aspetti epidemiologici. [http://www.epicentro.iss.it/problemi/infezioni_correlate/ epid.asp.2009].

2. Stronati $M$, et al: Sepsi Neonatali: nuove strategie preventive. Minerva Pediatr 2013, 65:103-110.

3. Garland JS, Uhing MR: Strategies to prevent bacterial and fungal infection in the neonatal intensive care unit. Clin Perinatol 2009, 36(1):1-13. 
4. Polin RA, Denson S, Brady MT: Committee on Fetus and Newborn; Committee on Infectious Diseases. Strategies for prevention of health care-associated infections in the NICU. Pediatrics 2012, 129:e 1085-1093.

5. World Health Organization: Guidelines on hand hygiene in health care: First global patient safety challenge clean care is safer care". WHO; 2009.

6. CDC: Guidelines for the Prevention of Intravascular Catheter-Related Infections. MMWR 2002, 51.

7. CDC: Guidelines for the Preventing Health-Care-Associated Pneumonia. 2003.

8. Adamkin DH: Mother's milk, feeding strategies, and lactoferrin to prevent necrotizing enterocolitis. JPEN J Parenter Enteral Nutr 2012, 36(1, Suppl):25S-29S.

9. Isaacs D: Unnatural selection: reducing antibiotic resistance in neonatal units. Arch Dis Child Fetal Neonatal Ed 2006, 91:F 72-74.

10. Fanos V, Cuzzolin L, Atzei A, Testa M: Antibiotics and antifungals in neonatal intensive care units: a review. J Chemother 2007, 19:5-20.

11. Manzoni P, et al: Italian Task Force for the Study and Prevention of Neonatal Fungal Infections-the Italian Society of Neonatology. Bovine lactoferrin prevents invasive fungal infections in very low birth weight infants: a randomized controlled trial. Pediatrics 2012, 129:116-123.

12. Alfaleh $K$, Anabrees J, Bassler D, Al-Kharfi T: Probiotics for prevention of necrotizing enterocolitis in preterm infants. Cochrane Database Syst Rev 2011, , 3: CD005496.

13. Manzoni P, De Luca D, Stronati M, Jacqz-Aigrain E, Ruffinazzi G, Luparia M, Tavella E, Boano E, Castagnola E, Mostert M, Farina D: Prevention of nosocomial infections in neonatal intensive care units. Am J Perinatol 2013, 30(2):81-88.

doi:10.1186/1824-7288-41-S1-A43

Cite this article as: Stolfi et al.: Old and new strategies for the prevention of nosocomial infections. Italian Journal of Pediatrics 2015 41(Suppl 1):A43.

\section{Submit your next manuscript to BioMed Central and take full advantage of:}

- Convenient online submission

- Thorough peer review

- No space constraints or color figure charges

- Immediate publication on acceptance

- Inclusion in PubMed, CAS, Scopus and Google Scholar

- Research which is freely available for redistribution

Submit your manuscript at www.biomedcentral.com/submit 